\author{
Г.К.Шолпанқұлова ${ }^{1}$ А.К.Садық̆ова ${ }^{2}$ \\ ${ }^{12}$ Л.Н.Гумилев атындавы Еуразия ұлттық университеті \\ Нұр-Сұлтан к., Қазақсстан

\section{БОЛАШАҚ МАМАНДАРДЫ ӘЛЕУМЕТТІК СЕРІКТЕСТІК ЖАҒДАЙЫНДА ДАЙЫНДАУДЫН ЕРЕКШЕЛІКТЕРІН КОМПАРАТИВТІ ТАЛДАУ}

\begin{abstract}
Аң̧датпа
Бұл мақалада болашақ мамандарды (біздің контекстімізде, әлеуметтік педагогтарды) әлеуметтік серіктестік жағдайында дайындаудың ерекшеліктері қарастырылады және салыстырмалы талдау жасалады (үш елдің: Қазақстан, Ресей және АҚШ тәжірибелерін салыстыру негізінде). Әлеуметтік серіктестік ұғымы сан алуан түрлі ғылымда әртүрлі мағынада түсіндіріледі: топтық және корпоративтік қызығушылықтарды ескере отырып, жалпы ұлттық мүдделерге жетуге бағдарланған түрлі әлеуметтік субъектілердің қарым-қатынас жүйесі ретінде (философиялық аспект); әлеуметтікеңбек қатынастары саласындағы қызметкерлердің, жұмыс берушілердің және мемлекеттің ынтымақтастығына бағытталған шаралар жүйесі ретінде (экономикалық-құқықтық аспект); таптық күрес теориясының орнына келген субъектілер арасындағы өзара қарым-қатынастар жүйесі ретінде (тарихи аспект). Біз қарастырып отырған білім беру саласында серіктестік қарым-қатынас үлгісі ерекшеленеді, өйткені білім беру саласындағы әлеуметтік серіктестік үлгілерінің өзіндік ерекшелігі білім алу қажеттілігімен және білім беру қызметтеріне сұраныспен түсіндіріліп, халықтың жұмыспен қамтылу деңгейінің және құрылымының өзгеруімен анықталады. Мысалы, Батыс Еуропа экономикасын жаңа технологиялық базисте қайта құру 70-ші жылдары құрылымдық жұмыссыздықтың күшеюін тудырды, дәл сол кезде мемлекеттің, кәсіпкерлер мен қызметкерлердің мүдделерін келісуді жеңілдететін білім беру саласында тиісті реформалар жүргізілді. Қазіргі уақытта білім беру саласындағы әлеуметтік серіктестік моделі кәсіптік білім беру мен оқыту жүйесіне мемлекеттік қатысу дәрежесі және әлеуметтік серіктестердің қажеттілігі мен олардың күш-жігерін біріктіру қабілеті сияқты айырмашылықтарға ие.
\end{abstract}

Түйін сөздер: серіктестік, әлеуметтік серіктестік, компаративті талдау, білім беру, білім беруді жаңғырту.

\author{
Sholpankulova G.K. ${ }^{1}$, Sadykova A.A. ${ }^{2}$ \\ ${ }^{12}$ L.N. Gumilyov Eurasian National University, \\ Nur Sultan, Kazakhstan
}

\title{
COMPARATIVE ANALYSIS OF THE PECULIARITY OF PREPARING FUTURE SPECIALISTS IN THE CONDITIONS OF SOCIAL PARTNERSHIP
}

Abstract
This article discusses the features of training future specialists (in our society, social educators) in the context of social cooperation and comparative analysis (based on a comparison of the experience of three countries: Kazakhstan, Russia and the USA). The term "social partnership" in various sciences is interpreted differently: as a system of relations between various social entities, which is oriented towards achieving national interests, taking into account group and corporate interests (philosophical aspect); as a system of measures aimed at cooperation between workers, employers and the state in the field of social and labor relations (economic and legal aspect); as a system of relationships between these entities, which replaced the theory of class struggle (historical aspect). In our field of education, the model of partnerships is different, since the specificity of models of social partnership in the field of education is explained by the fact that the need for knowledge and the demand for educational services are determined by changes in the level and structure of employment. For example, the restructuring of the West European economy on a new technological basis in the 70s caused an increase in structural unemployment, and it was then that the relevant reforms in the field of education were carried out, which facilitated the coordination of the interests 
of the state, entrepreneurs and workers. Currently, the model of social partnership in the field of education has such differences as the degree of state participation in the system of vocational education and training and the presence of the needs of social partners and their abilities to combine efforts.

Key words: partnership, social partnership, comparative analysis, education, modernization of education.

\author{
Г.К.Шолпанкулова ${ }^{1}$, А.А.Садыкова ${ }^{2}$ \\ ${ }^{12}$ Евразийский национальный университет им. Л.Н.Гумилева \\ 2. Нур-Султан, Казахстан
}

\title{
КОМПАРАТИВНЫЙ АНАЛИЗ ОСОБЕННОСТИ ПОДГОТОВКИ БУДУЩИХ СПЕЦИАЛИСТОВ В УСЛОВИЯХ СОЦИАЛЬНОГО ПАРТНЕРСТВА
}

\begin{abstract}
Аннотация
В данной статье рассматриваются особенности подготовки будущих специалистов (в нашем контексте - социальные педагоги) в условиях социального партнерства и проводится компаративный анализ (на основе сравнения опыта трех стран: Казахстан, Россия и США). Термин «социальное партнерство» в различных науках трактуется по-разному: как система отношений различных социальных субъектов, которая ориентирована на достижение общенациональных интересов, при учете групповых и корпоративных интересов (философский аспект); как система мер, направленных на сотрудничество работников, работодателей и государства в сфере социально-трудовых отношений (экономико-правовой аспект); как система взаимоотношений между названными субъектами, пришедшая на смену теории классовой борьбы (исторический аспект). В рассматриваемой нами сфере образования модель партнерских отношений отличается, поскольку специфичность моделей социального партнерства в сфере образования объясняется тем, что потребность в знаниях и спрос на образовательные услуги определяются изменениями уровня и структуры занятости населения. К примеру, перестройка западноевропейской экономики на новом технологическом базисе в 70-х годах вызвала усиление структурной безработицы, и именно тогда были проведены соответствующие реформы в сфере образования, облегчившие согласование интересов государства, предпринимателей и работников. В настоящее время модель социального партнерства в сфере образования имеет такие отличия, как степень государственного участия в системе профессионального образования и обучения и наличие потребностей социальных партнеров и их способностей объединить усилия.

Ключевые слова: партнерство, социальное парнерство, компаративный анализ, образование, модернизация образования.
\end{abstract}

Қазақстан Республикасының Тұңғыш Президенті - Елбасы Н.Ә.Назарбаевтың жаңғырту барлық қазақстандықтарға қажет. Осындай түсіністік жағдайында ғана кең көлемді қоғамдық консенсус пен табысқа қол жеткізуге болады. Үшіншіден, әріптестік қатысу қағидаты. Барлық жұмыс мемлекеттің, бизнес пен азаматтың тығыз өзара іс-қимылы негізінде құрылуы тиіс. Бұл жерде биліктің міндеті мемлекет, қоғам мен жеке адам мүддесінің рационалды тепе-теңдігін қамтамасыз ету. Шынайы әділеттілік дегеніміз, міне, осы. Әлеуметтік әріптестікті белсенді дамыту, елдің мемлекеттік емес секторын, бірінші кезекте, әлеуметтік саланы жаңғыртуға қатысуын кеңейту үшін жағдай жасау маңызды. Сондықтан «мемлекет пен бизнес тек экономикалық қана емес, әлеуметтік мәселелерді шешуде толыққанды серіктес болуы тиіс» - деп тұжырымдауы қарастырылып отырылған мәселенің өзектілігін айқындай түседі [1].

Мемлекет саясаты білім беру ұйымдарының әлеуметтік серіктестік желісін кеңейтуге, түрлі әлеуметтік институттармен ынтымақтастыққа бағытталған. Бұл тенденция немесе үрдіс Қазақстан Республикасын әлеуметтік дамытудың 2030 жылға дейінгі тұжырымдамасын және Әлеуметтік жаңғыртудың 2016 жылға дейінгі кезеңге арналған жоспарын бекіту туралы Қазақстан Республикасы Үкіметінің 2014 жылғы 24 сәуірдегі № 396 қаулысында көрініс тапты [2].

Сонымен бірге Қазақстан Республикасының Президенті-Елбасы белгілеген Ұлт жоспары - бес институционалдық реформаны жүзеге асыру жөніндегі 100 қадамды іске асыру шеңберінде (83қадам. Еңбек қатынастарын ырықтандыру) Қазақстан Республикасының жаңа Еңбек кодексі әзірленіп, 2016 жылғы 1 қаңтардан бастап қолданысқа енгізілді [3]. 
Бүгінгі таңда білім беру саласы мен еңбек саласы арасындағы байланыс едәуір дәрежеде бұзылған, бұл өндірістік саланы дамытудың жаңа әлеуметтік-экономикалық факторларынан және оның ішінде кәсіптік білім беру саласында әлеуметтік серіктестіктің жеткіліксіз ұйымдастырылуынан туындады. Кәсіптік білім беру жүйесінде мәселенің өзектілігі білім беру ұйымдары мен жұмыс берушілер тарапынан бітірушіге қойылатын талаптар арасындағы қарама-қайшылықтарды шешуде әлеуметтік серіктестікке ерекше рөл беріледі.

Сонымен қатар заманауи серіктестік қарым-қатынастар кәсіптік білім беруді жаңғыртумен байланысты мәселелер кешенін шешу ресурсы ретінде заманауи ұйымдық формаларды талап етеді. Қоғамдық даму міндеттерін шешу осы қоғамды жетілдіруге бағытталған жүйенің жоғары білікті кадрларын даярлауға, рухани-адамгершілік тұлғаны тәрбиелеуге, азаматты қалыптастыруға даярлау деңгейіне тікелей тәуелді болады.

Осы тұрғыда зерттеудің мақсаты әлемдік жоғары білім беру кеңістігінде болашақ мамандарды серіктестік жағдайында дайындауды сүйемелдеу технологиясына салыстырмалы талдау жасау негізінде АҚШ, Ресей және Қазақстандағы тәжірибелерді саралап, нәтижесінде отандық серіктестік жағдайында сүйемелдеу технологиясын дамытуға бағытталған нұсқаларды әзірлеу. Бұл компаративті талдау мынадай міндеттерді шешуге мүмкіндік береді: әлемдік және отандық жоғары білім берудегі болашақ мамандарды серіктестік жағдайында дайындауды сүйемелдеу технологиясының жетекші тенденцяларын, негізгі қағидаларын анықтау және жүйелеу; әлемдік білім беру кеңістігі мен отандық білім берудегі серіктестік жағдайында болашақ кадрларды дайындаудағы технологиялардың ерекшеліктерін ашу; әлемдік және отандық жоғары білім берудегі сүйемелдеу технологияларын салыстыру және өз елімізге тиімді бағыттарын енгізу; т.б.

Әлеуметтік серіктестік мәселесі пәнаралық зерттеу феномені. Оның қайнар көздеріне экономика саласындағы әзірлемелер (В.П.Киселев, В.Г.Смольков), нормативтік-құқықтық қатынастар (Л.А.Гордон, К.Г.Митрофанов, Э.В.Клопов, Ю.Г.Одегов, Р.Г.Руденко, И.Г.Шаблинский) әлеуметтік серіктестік тиімділігінің (В.А.Борисов, А.В.Ветров, К.Г.Кязимов) экономикалық және саяси тұрақтылығына қол жеткізу, оның қазіргі социумның әртүрлі мәселелерін шешудің тиімді тәсілі ретіндегі әмбебаптығы (В.В.Комаровский, Б.С.Модель, И.М.Модель) жатқызылады.

Білім қоғамның ең маңызды салаларының бірі ретінде оның әртүрлі құрылымдары (мәдениет, денсаулық сақтау, халықты жұмыспен қамту және әлеуметтік қорғау қызметтері, конфессиялық, ұлттық, қоғамдық ұйымдар және бірлестіктер) арасындағы шекаралардың шарттылығын қабылдайды.

Бүгінгі білім беру жалпы мемлекеттің өзекті экономикалық, әлеуметтік, мәдени мәселелерін шешуге бағытталған ашық жүйе, оның ішінде өзара әрекеттестіктің неғұрлым тиімді тәсілі ретінде әлеуметтік серіктестікті кеңейту есебінен өтуде.

Әлеуметтік серіктестік ғылыми әдебиеттерде және практикада сан алуан түрлі аспектіде сипатталады:

- әлеуметтік топтар, таптар, қауымдастықтар және олардың құрылымдары арасындағы қоғамдық қатынастардың өзіндік ерекше типі ретінде (В.Н.Якимец, Ф.С.Яруткина, А.А.Рыбина);

- мемлекеттік органдар, жұмысшылар және оларға жұмыс берушілер арасындағы өзара қарымқатынас тетігі ретінде (А.Т.Глазунов, Е.А.Рыкова);

- нарықтық экономикаға тән жалдамалы қызметкерлер мен жұмыс берушілердің тең құқылы ынтымақтастығын қамтамасыз ететін әлеуметтік-еңбек қатынасының ерекше типі ретінде (А.В. Корсунов, И.М. Реморенко, Н.В.Тюкалова).

А.А. Рыбина әлеуметтік серіктестікке «әртүрлі әлеуметтік топтардың бірлескен ұжымдық бөлінген қызметі ретінде барлық қатысушыларға оң яғни позитивті әсер қалдыратын іс-әрекет» деген әмбебап анықтама береді [4, б. 196].

Білім берудегі әлеуметтік серіктестікке анықтама бере отырып, зерттеушілердің әлеуметтік серіктестікті білім беру іс-әрекетінің тиімділігін арттыру мақсатындағы өзара әрекеттесу деп түсіндіруі ұқсастықты көрсетеді. Онда әлеуметтік серіктестіктің осы үдеріске қатысушылардың ерікті және тең құқылы сипатымен құрылуы маңызды болып табылады.

И.Н. Гаврилова әлеуметтік серіктестікті елдегі білім беру жүйесін дамыту, өз бетімен білім алумен бірге білім берудің барлық түріне қолайлы жағдай жасау бойынша қоғамдық секторлардың құрылымдық өзара әресеттесуі ретінде түсіндіреді [5, б. 226-247].

И.М. Залялетдинова әлеуметтік серіктестікті «білім беру ұйымдарының барлық тараптардың мүдделерін барынша келісуге және іске асыруға бағытталған еңбек нарығының субъектілерімен қарым-қатынасын сипаттайтын әлеуметтік өзара әрекеттестіктің бір түрі» ретінде анықтайды [6, б. 132].

В.А. Михеев бұл мәселені зерттей отырып, Ресейдегі әлеуметтік серіктестік жүйесін дамытуда еліміздің осы жүйеде қызмет ете алатын өзіндік жағдайын ескеру қажет деп есептейді. Әлеуметтік 
серіктестікті «сенім, жалпы мақсаттар мен құндылықтар, қатынастардың еріктілігі мен ұзақ мерзімділігімен» ерекшеленетін бірлескен іс-әрекеттің ерекше түрі ретінде түсіндіреді. Автордың пікірінше, басқа елдердегі серіктестік қарым-қатынасты дамытудың формалары мен әдістерін бейімдеу, әлеуметтік серіктестіктің пилоттық жобаларын жүзеге асыру қажет. [7, б. 6-17].

Н.В. Тюкалованың пікірінше, қалыптасқан әлеуметтік және экономикалық жағдайда білім беру ұйымдарының серіктестікке бағыттылығы қоғамның басқа салалармен (билік органдары, бизнес, басқа да білім беру ұйымдары, мәдениет және ғылым) өзара әрекеттесуге ұмтылысынан және екіжақтың да пайдалы ынтымақтастығын және бірлескен қызметін іске асыруын көрсетеді [8, б.16].

«Әлеуметтік серіктестік» терминін зерттеу тәсілдерін талдау бұл феноменнің қарым-қатынасты орнату тетігі ретінде түсіндірілетініне назар аудартады. Серіктестік топта өзара әрекеттесудің осындай түрін көздейді, оның негізі тең құқықтылыққа, өзара келісімге қол жеткізуге, адамдар арасындағы қатынастарды жақсартуға ұмтылу болып табылады.

Әлеуметтік серіктестік еңбек нарығының қажеттіліктеріне сәйкес жоғары білікті мамандарды даярлау саласын, кәсіпорындарды білікті бәсекеге қабілетті кадрлармен қамтамасыз ету, қызметкерлердің біліктілігін арттыру және бітіруші түлектерді жұмысқа орналастыру үшін жағдай жасау мәселелерін шешуге бағытталады. Білім беру ұйымдары үшін әлеуметтік серіктестік оқыту сапасын арттыру мақсатында ресурстарды тарту және тәжірибе алмасу. Білім беру ұйымдары мен өндіріс орындарының арасындағы әлеуметтік серіктестік бұл білім беру ұйымдары мен өндіріс орындарының бірлескен қызметі, еңбек нарығында сұранысқа ие болатын болашақ мамандардың дайындау сапасын жоғарылату мақсатын қамтамасыз етіп, педагогикалық және әлеуметтік экономикалық шешімдерді қабылдау және оларды іс жүзіне асыру болып табылады. Сондықтан әлеуметтік серіктестіктің қазіргі заманғы білім беру мен социум субъектілерінің өзара әрекеттестігінің түрі ретіндегі қажеттілігі бұл идеяны түсінетін және қабылдайтын ғана емес, оны нақты тәжірибеде іске асыратын педагогтарды мақсатты дайындау мәселесін тудырады.

ЖОО-ның педагогикалық мамандықтар студенттерін әлеуметтік серіктестікке мақсатты дайындаудың маңыздылығы білім берудегі 6В01- «Педагогикалық ғылымдар» бағыты, атап айтқанда, біздің зерттеу контекстімізде 6В018- «Әлеуметтік педагогика және өзін-өзі тану мамандарын дайындау бағыттары» бойынша бакалавриаттың білім беру бағдарламасын меңгеру нәтижелеріне қойылатын талаптарда қарастырылады. Болашақ бакалаврлардың жалпы мәдени және кәсіптік құзыреттіліктері білім беру ұйымдарының әлеуетті серіктестері шеңберін, оку - тәрбие үдерісінің сапасын қамтамасыз етуге мүдделі әріптестермен, әлеуметтік серіктестермен өзара әрекеттесу қабілетін анықтай білудің маңыздылығын көрсетеді.

Әлемдік тәжірибеге назар аударатын болсақ, Ресейдің білім беру саласындағы әлеуметтік серіктестік жүйесінің қарқынды дамуы Еуропалық қоғамдастық елдерінің тәжірибесін қамтитын ғылыми және практикалық тұрғыдан орта жалпы және орта, жоғары кәсіптік білім беруді ықпалдастыру арқылы білім беру қызметінің тиімділігін қамтамасыз етеді және білім беру ұйымдары мен кәсіпорындар арасындағы өзара қарым-қатынасты дамытудың іргетасы болып табылады. Ресей Федерациясының Еңбек кодексінде әлеуметтік серіктестіктің рөлі заң жүзінде тіркелген. Мұнда «әлеуметтік серіктестік қызметкерлер және олардың өкілдері, жұмыскерлердің өкілдері және олардың өкілеттіктері, жұмыс берушілер және олардың өкілдері, мемлекеттік билік органдары немесе жергілікті өзін-өзі басқару, соның ішінде бейресми, құқықтық сипаттағы емес органдары арасындағы өзара әрекеттестіктің барлық түрін қамтитын жүйе ретінде анықталады [9].

И.А.Артемьев әлеуметтік серіктестік жағдайында орта жалпы және орта кәсібіи білім берудің интеграциясы мәселесін зерттей отырып, Ресей Федерациясындағы әлеуметтік серіктестіктің даму кезеңдерін үшке бөліп, былайша сипаттайды: бастапқы кезең - серіктестік қатынастардың пайда болуы, әлеуметтік әріптестік жүйесі туралы ғылыми түсініктердің қалыптасуы, әртүрлі салаларда, соның ішінде білім беруде оның құрылымдық элементтері арасында өзара байланысты орнату, әлеуметтік серіктестік жүйесінің заңнамалық базасын, оның технологиясын дайындау; даму кезеңі әлеуметтік серіктестік тұтас ашық жүйе ретінде түсініледі, экономикалық және әлеуметтік дамудың қоғамдық жүйесіне кеңінен енгізіледі: әлеуметтік серіктестік жүйесіне енгізілген құрылымдардың өкілдерімен биліктің барлық деңгейлеріндегі құрылымдардың өзара әрекеттесу тетігін жетілдіру, әлеуметтік саладағы тиімді әріптестікті дамыту, қоғамның саяси және рухани өмірін жариялауда БАК рөлін арттыру, серіктестік қатынастарды дамытумен және оны іске асыруға мүдделі тараптардың өзара қарым-қатынастарын реттеумен айналысатын мамандарды даярлау, сараптамалық баға беруге, объективті шешуге, сындарлы баға жасауға қабілетті тәуелсіз ұйымдардың жұмысын реттеу бойынша 
ұсыныстар; жетілдіру кезеңі - білім беруді жаңғырту мен экономикалық даму тетігі ретінде әлеуметтік серіктестік жүйесін ары қарай жетілдіру [10, б. 53-54 ].

Тасис Петер Камб жоба сарапшысы ретінде өз зерттеуінде жалпы мектептік және кәсіптік білім беру жүйесіндегі әлеуметтік серіктестік мәселесін Германияның білім алушыларды кәсіби бағдарлау, бастауыш кәсіби біліктілігін меңгеру және мамандардың біліктілігін арттыру мақсатында әлеуметтік серіктестік жүйесін қолданудың көпжылдық тәжірибесіне сүйеніп сипаттайды [11, б.18-26].

Е.Ю. Закирова қазіргі өндірістің кадрлық мәселелерін шешудің екі жолын анықтайды. Бірінші жол - бұл әлеуметтік серіктестік бағдарламасы бойынша оқу орындарымен ынтымақтастықта мамандарды бірлесіп даярлау немесе еңбек нарығына қажетті білімі бар мамандарды іздестіру. Екінші жол - корпоративтік білім беруді құруды, яғни жұмыс беруші есебінен компания қызметкерлерін оқытуды, қайта даярлауды және біліктілігін арттыруды көздейді [12, б.59-62].

Жоғарыдағы ғылыми зерттеу жұмысын зерделеу екінші бағыт бойынша барлық елдердің тәжірибесінде жұмыстар жүргізіліп жатқанын көрсетеді. Әлеуметтік-экономикалық модернизация немесе жаңғырту үрдістері кәсіптік білім берудің практикалық-бағдарлық секторын кеңейтуге септігін туғызады. Қазіргі заманғы әлеуметтік-экономикалық жағдайларда әлеуметтік серіктестік жүйесін қалыптастыру ұзақ және күрделі үдеріс, ол бірқатар субъективті және объективті себептерге байланысты: экономика жағдайы, әлеуметтік жағдай, оқу орындары басшыларының мүмкіндіктері, билік органдарының серіктестік қарым-қатынастар жүйесіне қосылуға дайындығы және т.б.

Қазіргі заманның әлеуметтік-мәдени жағдайындағы негізгі тенденция өз балаларын әлеуметтендірудің қажетті деңгейін қамтамасыз ету мақсатында ата-аналар қоғамының білім беру ұйымдарымен белсенді ынтымақтасуға, серіктестік қарым-қатынастарға қатысуға дайындығы байқалады Бұл ретте оқу орнының әлеуметтік серіктестерімен жұмыстарының нәтижелігі мен тиімділігі өз мүдделерінің іске асырылу дәрежесімен анықталады және өзінің негізгі әлеуметтік функциясын орындау дәрежесі бойынша бағаланады. Сондықтан бұл заманауи әлеуметтік-экономикалық жағдайда әлеуметтік серіктестік жүйесін қалыптастырумен тығыз байланысты (1-сурет).

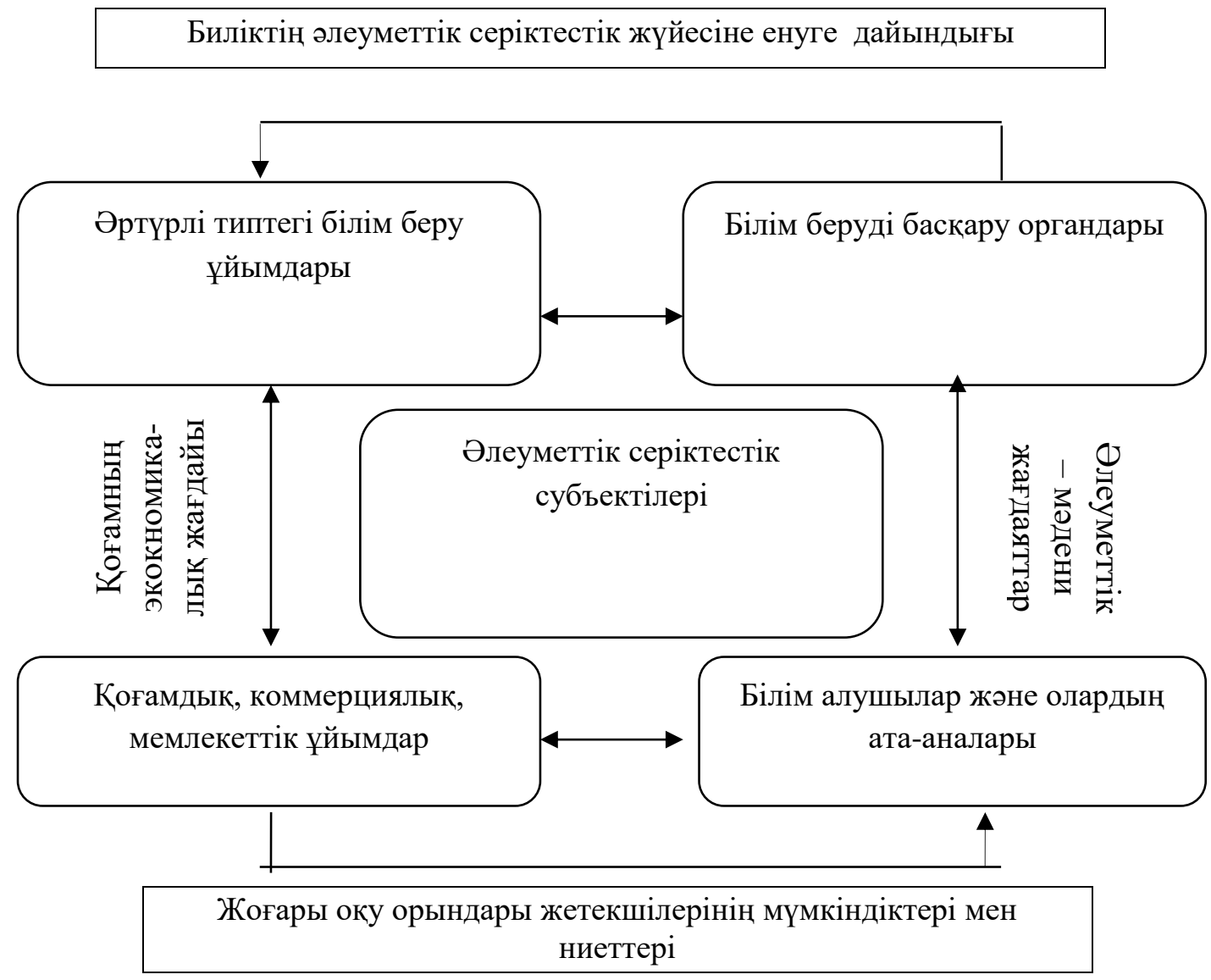

Сурет 1 - Әлеуметтік серіктестік жүйесін қалыптастыру (И.А.Артемьев бойынша) 
И.А.Артемьевтің пікірінше, жалпы орта білім беру ұйымдарындағы әлеуметтік серіктестіктің ерекшелігі әлеуметтік серіктестік субъектілеріне түрлі үлгідегі білім беру ұйымдары, білім беруді басқару органдары, қоғамдық, коммерциялық, мемлекеттік ұйымдар, білім алушылар жатқызылуы болып табылады. Бұл ретте ата-аналар мектептің ең маңызды әлеуметтік серіктестерінің бірі екенін ескеру қажет. Мұнда мектеп пен отбасының серіктестік қарым-қатынасы білім беру ортасындағы субъектілік қатынас саласын кеңейтуге, ата-ананың психологиялық-педагогикалық сауаттылығын арттыруға, білім беру мазмұнына оқушылар мен ересектердің бірлескен іс-әрекеттерін де ендіруге мүмкіндік туғызады [10, б. 59].

Білім беру ұйымдарының әлеуметтік серіктестермен өзара әрекеттестігінің келісім-шарттық және ұйымдастырушылық формалары бар. Өзара әрекеттестіктің келісім-шарт формасы практикаларын (оқу практикасы, психологиялық-педагогикалық, педагогикалық, өндірістік педагогикалық), оқытушылар құрамының тағылымдамасын өтуді ұйымдастыруға, сонымен бірге жоба және ғылымизерттеу жұмыстарын бірлесіп әзірлеуге және оларды іске асыруға мүмкіндік береді.

Кәсіби білім беруге қатысты әлеуметтік серіктестік ұғымын зерттеуші педагогтар білім беру жүйесі қызметкерлерінің экономика және қоғамдық өндірістің түрлі салаларының өкілдерімен байланысуы ретінде қарастырады. Білім беру үдерісіндегі әлеуметтік серіктестіктің ерекшеліктерін зерттей отырып, Т.П. Грибоедова білім беру саласындағы серіктестік субъектілердің бір-біріне тікелей немесе жанама әсер ету үдерісі ретінде сипатталады деп тұжырымдайды [13, б.50-60].

Сондықтан әлеуметтік серіктестіктің білім беру саласына қолданылу жағдайын бағалау төмендегі 1-кестеде ұсынылады.

Кесте 1- Деңгейі бойынша әлеуметтік серіктестіктің жіктемесі (Т.П. Грибоедова бойынша)

\begin{tabular}{|c|c|c|c|}
\hline \multirow{3}{*}{\begin{tabular}{l}
\multicolumn{1}{l}{ Өлеуметтік } \\
серіктестік \\
параметрлері \\
Серіктестіктің \\
бағыттары
\end{tabular}} & \multicolumn{3}{|l|}{ Серіктестіктің деңгейлері } \\
\hline & Төмен & Орта & Жоғары \\
\hline & $\begin{array}{l}\quad \text { Кәсіби білім беру } \\
\text { ұйымдарының } \\
\text { локальдық мәселелерін } \\
\text { шешу }\end{array}$ & $\begin{array}{l}\quad \text { Кәсіби білім беру } \\
\text { ұйымдарының } \\
\text { мәселелерін } \\
\text { шешу }\end{array}$ & $\begin{array}{l}\text { Әлеуметтік-білім беру } \\
\text { мәселелерін шешу }\end{array}$ \\
\hline $\begin{array}{l}\text { Серіктестіктің } \\
\text { суб̆ъектілері }\end{array}$ & $\begin{array}{l}\text { Педагогикалық ұжым, } \\
\text { студенттер }\end{array}$ & $\begin{array}{l}\text { Педагогикалық ұжым, } \\
\text { студенттер, ата-аналар, } \\
\text { білім беру } \\
\text { ұйымдарының кеңестері, } \\
\text { қамқоршылық кеңес }\end{array}$ & \begin{tabular}{l}
\multicolumn{2}{r}{ Педагогикалық ұжым, } \\
студенттер, ата-аналар, \\
білім \\
ұйымдарының кеңестері, \\
инвесторлар, әлеуметтік \\
серіктес
\end{tabular} \\
\hline $\begin{array}{c}\text { Серіктестерді } \\
\text { қатыстыру немесе тарту }\end{array}$ & Қайырымдылық & $\begin{array}{l}\text { Инвестициялар, } \\
\text { демеушілік }\end{array}$ & $\begin{array}{c}\text { Инвестициялар, } \\
\text { әлеуметтік серіктестер }\end{array}$ \\
\hline Ресурстарды іске қосу & $\begin{array}{l}\text { Материалдық, } \\
\text { қаражаттық }\end{array}$ & $\begin{array}{l}\text { Қаражаттық, кадрлік, } \\
\text { ұйымдастырушылық }\end{array}$ & $\begin{array}{l}\text { Қаражаттық, кадрлік, } \\
\text { ұйымдастырушылық }\end{array}$ \\
\hline $\begin{array}{c}\text { Серіктестіктің } \\
\text { уақыттықшеңбері }\end{array}$ & Бір реттік & Мерзімді & Тұрақты, ұзақ \\
\hline $\begin{array}{l}\text { Серіктестікті } \\
\text { нормативтік қамтамасыз } \\
\text { ету }\end{array}$ & Жоқ & $\begin{array}{c}\text { Білім } \quad \text { беру } \\
\text { ұйымдарындағы } \\
\text { локальдық актілер }\end{array}$ & $\begin{array}{l}\text { Келісім, } \\
\text { келісім-шарттар, } \\
\text { шарттар }\end{array}$ \\
\hline Серіктестік саласы & Білім беру ұйымдары & $\begin{array}{c}\text { Білім беру ұйымдары, } \\
\text { мемлекеттік органдар }\end{array}$ & $\begin{array}{l}\text { Білім беру ұйымдары, } \\
\text { мемлекеттік органдар, } \\
\text { бизнес-қоғамдастық }\end{array}$ \\
\hline
\end{tabular}


Кестеде көрсетілгендей, әлеуметтік серіктестік білім беру ұйымының материалдық-техникалық базасын жаңартуды, жаңа білім беру технологияларын енгізуді, оку-тәрбие үдерісін жетілдіруді және басқарудың жаңа жүйесін қалыптастыруды қамтамасыз ететін жеке тұлғаның дамуына және студенттердің кәсіби біліктілігін бекітуге ықпал етеді.

Сондықтан, әлемдік жоғары білім беру кеңістігінде болашақ мамандарды әлеуметтік серіктестік жағдайында дайындау үрдісінде сүйемелдеу технологияларын қолдану тәжірибесіне салыстырмалы талдау жасалып, мазмұндық тұрғыдан сипатталады (2-кесте).

Кесте 2- Болашақ мамандарды әлеуметтік серіктестік жағдайында дайындаудың ерекшеліктерін компаративті талдау

\begin{tabular}{|c|c|c|c|}
\hline $\begin{array}{l}\text { Концептуальдық } \\
\text { мәліметтері }\end{array}$ & АKШІІ & Ресей & $\begin{array}{c}\text { Қазақстан } \\
\text { Республикасы }\end{array}$ \\
\hline \multicolumn{4}{|c|}{ 1.Серіктестік жағдайында дайындаудағы сүйемелдеу технологиялары жайлы жалпы мәліметтер } \\
\hline Тарихы & Бірнеше ғасырлық тарихы бар & Практикалық тәжірибесі бар & Жаңа тенденция \\
\hline Конщепту альдықнегіздері & $\begin{array}{l}\text { Мемлекеттік-мүдделік, жекелік, } \\
\text { жалпылық, әлеуметтік, } \\
\text { экономпкалық, этномәденилік. } \\
\text { Жүйелілік тұғыр қалыптасқан, } \\
\text { оның нәтюжесінде болашақ } \\
\text { мамандарда түйіндік құзіреттілік } \\
\text { қалыптасқан. }\end{array}$ & $\begin{array}{l}\text { Құзіреттілік тұғыр, ұжымда } \\
\text { нәтюелі өзара әрекеттесу, } \\
\text { қоғамға құндылық ретінде қарап, } \\
\text { диалектикалық бірлік таныту. }\end{array}$ & $\begin{array}{l}\text { Құзіреттілік тұғыр даму } \\
\text { үрдісінде, практикалық білімнің } \\
\text { аздығынан сұранысқа не емес. }\end{array}$ \\
\hline Модель & 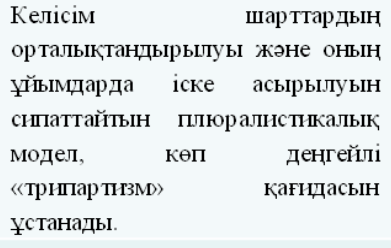 & $\begin{array}{lr}\text { Практикаға } & \text { бағытталған, } \\
\text { ұйымдастыру } & \text { сипатында, көп } \\
\text { деңгейлі } & \text { «трипартизм» } \\
\text { қағидасын ұстанады, ашық білім } \\
\text { беру кеңістігі. }\end{array}$ & $\begin{array}{l}\text { Практикаға бағытталған, } \\
\text { ұйымдастырушылық сипатта, } \\
\text { көп деңгейлі «трипартизм } \\
\text { қағидасын ұстанады, ашық білім } \\
\text { беру кеңістігі. }\end{array}$ \\
\hline \multicolumn{4}{|c|}{ 2.Серіктестік барысындағы қатысатын субьектілер } \\
\hline $\begin{array}{l}\text { Серіктестік } \quad \text { жағдайында } \\
\text { даярланатын кадрлар }\end{array}$ & $\begin{array}{l}\text { Кәсіби } \\
\text { берушілер, } \\
\begin{array}{l}\text { мемлекеттік } \\
\text { ұлттық өкімет, }\end{array}\end{array}$ & $\begin{array}{l}\text { Мемлекет, кәсіподақ, жұмыс } \\
\text { берушілер, жұмысшылар }\end{array}$ & $\begin{array}{l}\text { Мемлекет, кәсіподақтар, жұмыс } \\
\text { берушілер, жұмысшылар }\end{array}$ \\
\hline $\begin{array}{l}\text { Жұмыс беруші мен болашақ } \\
\text { маманды дайындау арасындағы } \\
\text { өзарақарым қатынас. }\end{array}$ & $\begin{array}{l}\text { Уннверсалды әрекеттесу арнайы } \\
\text { әрекеттесуге ұштасады. }\end{array}$ & Уннверсалды әрекеттесу. & Уннверсалды әрекеттесу. \\
\hline \multicolumn{4}{|c|}{ 3. Сүйемелдеу технологияларынұйымдастыру } \\
\hline Мақсаты & $\begin{array}{l}\text { Әр студентті ұжымдық және } \\
\text { жеке дербес, субъекті ретінде } \\
\text { қалыптастыру }\end{array}$ & $\begin{array}{l}\text { Студентті жаңа ортаға } \\
\text { бейімделіп, негізгі қызметтерін } \\
\text { жүзеге асыруғақолдау көрсету. }\end{array}$ & $\begin{array}{l}\text { Студентті жаңа ортаға } \\
\text { бейімделіп, негізгі қызметтерін } \\
\text { жүзеге асыруға қолдау көрсету. }\end{array}$ \\
\hline Мазмұны & $\begin{array}{l}\text { Өзара байланыс жасау, екі } \\
\text { немесе үш жақтың да мүддесін } \\
\text { ескеріп сапалы байланыс орнату. }\end{array}$ & $\begin{array}{l}\text { Студенттердің болашақ } \\
\text { жұмысының образын құру, } \\
\text { мүдделердің теңдігі. }\end{array}$ & $\begin{array}{l}\text { Студенттердің болашақ } \\
\text { жұмысының образын құру, } \\
\text { мүдделердің теңдігі. }\end{array}$ \\
\hline Формалары & $\begin{array}{l}\text { Жеке және топтық түрде } \\
\text { кеңестер алу }\end{array}$ & - & - \\
\hline Әдіс тәсілдері & $\begin{array}{l}\text { Белсенді тәсілдер жиынтығы, } \\
\text { жобалау, бақылау, диалог } \\
\text { орнату, әңгімелесу. }\end{array}$ & - & - \\
\hline \multicolumn{4}{|c|}{ 4. Серіктестік жағдайында дайындаудың сүйемелдеу технологияларыныңнәтижелері } \\
\hline Серіктестік орнатудың нәпшжесі & $\begin{array}{l}\text { Субъектілердің } \\
\text { әрекеттесуі, } \\
\text { тиімділігі. }\end{array}$ & - & - \\
\hline $\begin{array}{l}\text { Жұмыс беруші мен даярлау } \\
\text { институтының } \\
\text { әрекеттесуінің нәтикелері }\end{array}$ & 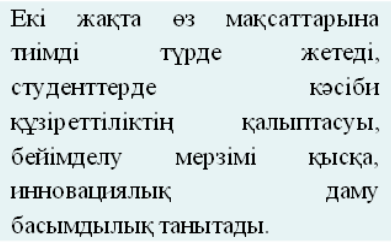 & - & - \\
\hline
\end{tabular}


Кестеде көрсетілгендей, әлеуметтік серіктестік субъектілері; әлеуметтік серіктестік органдары; әлеуметтік серіктестік деңгейлері; әлеуметтік серіктестік объектісі және әлеуметтік серіктестік қағидаттары Ресей мен АҚШ әлеуметтік серіктестік жүйесінің негізгі элементтері болып табылады. Бүгінгі таңда жоғары оқу орындары кәсіпорындардың өндірістік базасын өндірістік практиканың барлық түрлерін, курстық және дипломдық жобалау аясында студенттердің зерттеу жұмыстары үшін зертханалық және практикалық жұмыстарды жүргізу үшін пайдаланады.

Білім беру қызметінің жүйесі ретінде кәсіби білім беру іс-әрекеті мазмұнының түбегейлі өзгеруі «білім беру ұйымы - қоғам - өндіріс» триадасында тараптардың тиімді өзара әрекеттесуін білдіретін әлеуметтік серіктестік шеңберінде ұйымдастыру тетігін өзектендіреді.

Жоғары кәсіптік білім беруде жоғары оку орындарында білім алушылар үшін өндірістік практика өтетін ұйымдар (мектеп, колледж, т.б.) әлеуметтік серіктестік субъектілері болып саналады.

Бітіруші түлектің құзыреттілік моделін қалыптастыру үшін кәсіпорын мамандары нақты мамандықтар бойынша білім беру бағдарламаларының нәтижелі компонентін әзірлеуге белсенді түрде қатыстырылуда. Біздің зерттеу контекстімізде әлеуметтік педагогтарды дайындау үрдісіне қатысатын кафедра филалдары ретінде Нұр-Сұлтан қаласының жалпы білім беретін мектептерін, атап айтқанда, №80 мектеп-гимназиясын, Абай Құнанбайұлы атындағы №87 мектеп-гимназиясын, №22 мектеп-гимназиясын, сондай-ақ Нұр-Сұлтан қаласы әкімдігінің №2 «Психологиялық-педагогикалық түзеу кабинеті» коммуналдық мемлекеттік мекемесін атап өтуге болады. Л.Н.Гумилев атындағы Еуразия ұлттық университеті мен жоғарыдағы аталған білім беру ұйымдары арасында екі жақты келісім-шарт құрылған. Әлеуметтік серіктестік жағдайында неғұрлым тиімді өзара әрекеттестік үшін арнайы өкілеттіктер берген реттеуші құжаттар негізінде әрекет ететін ұйымдастырушылық құрылымдарды құру да көзделеді.

Сондықтан педагогикалық мамандықтар студенттерінің білім берудегі әлеуметтік серіктестікке дайындығы жалпымәдени және кәсіби құзыреттіліктермен қатар педагогикалық және әлеуметтік маңызды міндеттерді конструктивті шешу үшін қажетті әлеуметтік-педагогикалық құзыреттіліктердің (социумның түрлі өкілдерімен өзара әрекеттестікке тұрақты оң мотивация; әлеуметтік серіктестіктің ынтымақтастық, кооперация, консенсус, келісім-шарт, командалық өзара әрекеттестік тактикаларын меңгеруі, білім берудегі әлеуметтік серіктестермен өзара әрекеттестіке жекелік және кәсіби жауапкершілікке дайындығының болуы) қалыптасуын қамтиды.

Сонымен әлеуметтік серіктестік жүйесі қайырымдылық және қамқорлыққа алу сияқты өзара әрекеттестіктің басқа формаларынан айтарлықтай ерекшеленеді, ол ұзақмерзімде құрылып, бір реттік акциялармен шектелмей, білім беру ұйымдары мен оған қатысушыларды дамыту жағдаяттарын айтарлықтай жақсартуға ықпал етеді.

Қорыта келгенде, әлеуметтік серіктестік кәсіби білім берудің, мемлекеттік билік органдарының және жұмыс берушілердің консенсусқа қол жеткізу және әрбір тараптың қажеттіліктері мен мүдделерін қанағаттандыру мақсатында еріктілік, тең құқылық және әлеуметтік әділеттілік қағидаттары негізінде жүзеге асырылатын ұзақ мерзімді ынтымақтастық ретінде қарастырылады.

Демек, әлеуметтік серіктестіктің негізгі идеясы тараптардың толық құқылы серіктестігі негізінде өзара тиімді кооперация болып табылады. Әлеуметтік серіктестіктің құқықтық және реттеуші негізі ретінде маңыздылығын атай отырып, ол келесі міндеттерді шешуге арналған: кәсіптік білім беру ұйымының даму стратегиясын анықтау; білім беру мазмұнын толықтыру және құрылымын қалыптастыру; оқыту үдерісін ұйымдастыру; білім беру нәтижелерін үнемі бақылау; еңбек нарығын және мамандардың қажеттілігін зерттеу; кадрлық қамтамасыз ету және материалдық-техникалық базаны жаңғырту және қосымша қаржыландыру.

Пайдаланылван ддебиеттер тізімі:

1. Назарбаев Н.Ә. «Қазақстанның әлеуметтік жаңвыртылуы: Жалпыга Ортақ Еңбек Қогамына қарай 20 ққадам» бавдарламасы. 2012 жыл, 10 шілде. www.inform.kz/kz/nursultan-nazarbaevkazakstannyn-aleumettik-zhangyrtyluy-zhalpyga-ortak-enbek-kogamyna-karay-20-kadam_a2478341

2. Әлеуметтік жаңзвыртудың 2016 жылва дейінгі кезеңзе арналван жоспарын бекіту тураль Қазақсттан Республикасы Үкіметінің 2014 жылгы 24 сәуірдегі № 396 қ̧аулысыл.

3. Қазақстан Республикасының Еңбек кодексі, 2016 жыл 1 қаңтар. Қазақстан Республикасының Еңббек Кодексі Қазақсстан Республикасының Кодексі 2015 жылгы 23 қарашадавы № 414-V ҚРЗ.

4. Рыбина А.А. Сочиальное партнерствосубъектов образовательного пространства с представителями различных сфер экономики и общественной жизни как важнейшие условие 
Абай атындавы ҚазҰПУ-ц ХАБАРШЫСЫ «Педагогика вылымыдары»» сериясы, №2(66), 2020 ж.

подготовки учащейся молодежи $к$ социально-профессиональному самоопределению//Спрос и предложение на рынке труда и рынке образовательных услуг в регионах России: Сборник докладов по мат. Всероссийской научно-практической интернет-конфренции с международньм участием. Петрозаводск: ПетрГУ, 2004. - 268c.

5. Гаврилова И.Н. Социальное партнерство и образование//Непрерывное образование в политическом и экокномическом контекстах. - 2007. - №3. - С. 226-247.

6. Залялетдинова И.М. Взаимодействие профессионального образования с социальными партнерами как условие развития профессионально-языковой компетенции студентов вуза // Инновации в системе высшего образования: мат. ІІ Всероссийской науч.-метод. конф. - Челябинск, 2011. - C. 132.

7. Михеев В.А. Социальное партнерство в России: теоретико-концептуальные аспекты и перспективы развития/Под ред. Т.Раека, В.Г.Иванова//Сочиильное партнерство в образовательной сфере России: теория и практика. - М.: Изд-во РАГС, 1999. - 181c.

8. Тюкалова Н.В. Социальное партнерство в образовательной практике как фактор повьшения качества начального профессионального образования: автореф. дис. ... канд. пед. наук. - Ижевск, 2010. $-22 c$.

9. Трудовой кодекс Российской Федераџии (с измениями на 2018 год). Часть II, раздел 2, гл. 3-9.

10. Артемьев И.А. Интеграция среднего общего и среднего профессионального образования в условиях сочиильного партнерства: дисс.. канд. пед. наук. - Тверь, 2019. - 225c.

11. Камб Т.П.Социальное партнерство и соччиальный диалог в странах Европейского Сообщества/Под ред. В.А.Михеева//Социальное партнерство в образовательной сфере России: теория и практика: мат.международного семинара. - М.: Изд-во РАГС, 1999. -181с.

12. Социальное партнерство: учебное заведение-предприятие: методическое пособие/Закирова Е.Ю. //Под ред. Г.В.Мухаметзяновой. - Казань: ИПП ПО РАО, 2006. - 64c.

13. Грибоедова Т.П. Содержание понятия и особенности реализации социиального партнерства в современном образовании/Известия Рос. гос. пед. ун-та им. А.И.Гериена. - 2008. - №68. - С. 50-60.

\title{
МРНТИ 14.35.01
}

https://doi.org/10.51889/2020-2.1728-5496.29

\author{
А.М.Усенова ${ }^{1}$ М.М.Книсарина ${ }^{2}$ \\ ${ }^{1}$ Южно-Казахстанский Государственный Университетим М.Ауезова \\ ${ }^{2}$ Западно-Казахстанский медицинский университет имени Марата Оспанова
}

\section{КРЕАТИВНОСТЬ В АСПЕКТЕ РАЗВИТИЯ УПРАВЛЕНЧЕСКИХ УМЕНИЙ У ОБУЧАЮЩИХСЯ}

\author{
Аннотация
}

В статье предпринята попытка определить комплекс методов и средств по развитию креативности, как основополагающего компонентауправленческих умений у обучающихся. Анализ литературы, продуктов творческой деятельности студентов, результатов анкетного опроса подтверждают актуальность развития креативности в структуре управленческих умений обучающихся вуза. Был обобщен педагогический опыт преподавателей психолого-педагогических дисциплин в виде практических рекомендаций по развитию креативности мышления будущих специалистов в управленческом аспекте. Целесообразно учитывать условия стимулирования развитие творческого мышления, методические особенности применения творческих заданий, а также факторы, препятствующие развитию креативного подхода личности, как менеджера собственной деятельности, к решению образовательных и жизненных задач. Творческие задания в учебном процессе способствуют развитию у обучающихся их креативности, учебной мотивации, ответственности за свою учебную деятельность.

Ключевые слова. Управление, управленческие умения, успешная деятельность, обучающийся вуза, компетентность, креативность, творческий подход. 